\title{
Employability skills for the Romanian outsourcing industry
}

\author{
Ulrike Stefanie FOERSTER-PASTOR (FOERSTER-METZ) \\ The Bucharest University of Economic Studies, Bucharest, Romania \\ urike.s.foerster@web.de \\ Nina GOLOWKO \\ The Bucharest University of Economic Studies, Bucharest, Romania
}

\begin{abstract}
The Romanian outsourcing sector as part of the service sector has evolved enormously in the last decade in Romania. Foreign Direct Investments in this sector continue to grow, thus the sector employs more than 100.000 people in 2016 in Romania. However, companies claim not to get the right skills from employees which will allow them to move the latter from a purely service sector to more value-added services. Therefore, there is a need to generate a workforce with the necessary employability skills which will serve the industry, thus allowing the continuity of growth as well as permitting to be competitive in regards to other East European countries in the outsourcing industry as salaries rise in the Romanian industry and the industry is being pressured by the $4^{\text {th }}$ industrial revolution. So far, many Romanian studies have been done reflecting the skills need from the sector by using in first instance the questionnaire methodology or global surveys mostly on a very holistic view. This paper shows a new approach by deriving the skills needed by employers from their own data base: mainly job descriptions published in companies or recruitment sites by analysis of job entry positions. This allows a close and accelerated approach to define skills needed without a too high time delay in addition it permits to understand if the outsourcing industry is moving towards digitalization. The job descriptions are analyzed by using the method of qualitative content analysis according to Mayring (2014) using specific criteria based on literature review of employability skills. Key findings show that there is a need for specific skills technical skills but a trend to a higher demand in soft skills.
\end{abstract}

Keywords: employability, skills, outsourcing, Romania, competitiveness.

\section{Introduction}

Romania is on the head of moving up the ladder in terms of attractiveness for the Business Process Outsourcing (BPO) industry within the global landscape. The latest A.T Kearney Global Location Index Report 2016 shows that Romania moved up the ladder by 5 points to place number 13 following Poland (10), Vietnam (11) and Bulgaria (12). According to different sources the Romanian BPO industry is currently employing around 80 to 100 thousand employees and expects to grow this number by $15 \%$ to $17 \%$ each year, having approx. 5000 to 6000 open positions in the Business Process Services and Shared Services Centers in 2016 (Outsourcing Today, 2016). Currently the Romanian BPO industry demands for approx. 20000 employees per year. Because the economy is changing at fast pace and is becoming more digital, there is a particular demand for a variety of skills to serve and fit more added value projects which will allow a continual existence and even growth under the increasing pressure of rising labor costs and digitalization.

This raises the concern how the educational system together with the business outsourcing sector can comply with the workforce in demand. This paper aims to understand which employability skills are required by the BPO industry to continue to be competitive on a global level and to match with a digitalized world. For this purpose, the authors review the current state of literature regarding employability skills in general and 
with focus on the outsourcing industry and link both through an analysis of the required qualifications in job advertisements of the Romanian outsourcing industry.

\section{Literature Review}

Employability skills

Pursuant to the Oxford dictionary skill means either the ability to do something well (Synonyms: expertise, skillfulness, expertness, adeptness, adroitness, deftness, dexterity, ability, prowess, mastery, competence, competency, capability, efficiency, aptitude, artistry, art, finesse, flair, virtuosity, experience, professionalism, talent, cleverness, smartness, ingenuity, versatility, knack, readiness, handiness.) or a particular ability (Synonyms: accomplishment, strength, gift, forte) (Oxford Dictionary, 2017). Consequently, a great variety of definitions and classifications of employability skills can be found in literature. The following overview is an exemplary range of major traits and different approaches in this field.

Hillage and Pollard defined employability as the "capability to move self-sufficiently within the labor market to realize potential through sustainable employment" (Hillage and Pollard, 1998, p. 2). They focused on the individual's ability to cope with all phases of employment and thus identified

- employability assets (knowledge, skills, attitudes),

- deployment skills (career management skills, job skills),

- presentation skills (to get a job, e.g. CV writing and interview techniques) and

- personal circumstances (family responsibilities, external factors impact on whether someone can make the most of one's employability assets).

The universities' view is taken by Bowden. Employability skills are defined as "the qualities, skills and understandings a university community agrees its students would desirably develop during their time at the institution and, consequently, shape the contribution they are able to make to their profession and as a citizen" (Bowden (in Bridgstock, 2009, p. 32)).

Knight and Yorke (2003) defined four interrelated components with close linkages influencing employability in their USEM model, which is used in curriculum development (see figure 1). 


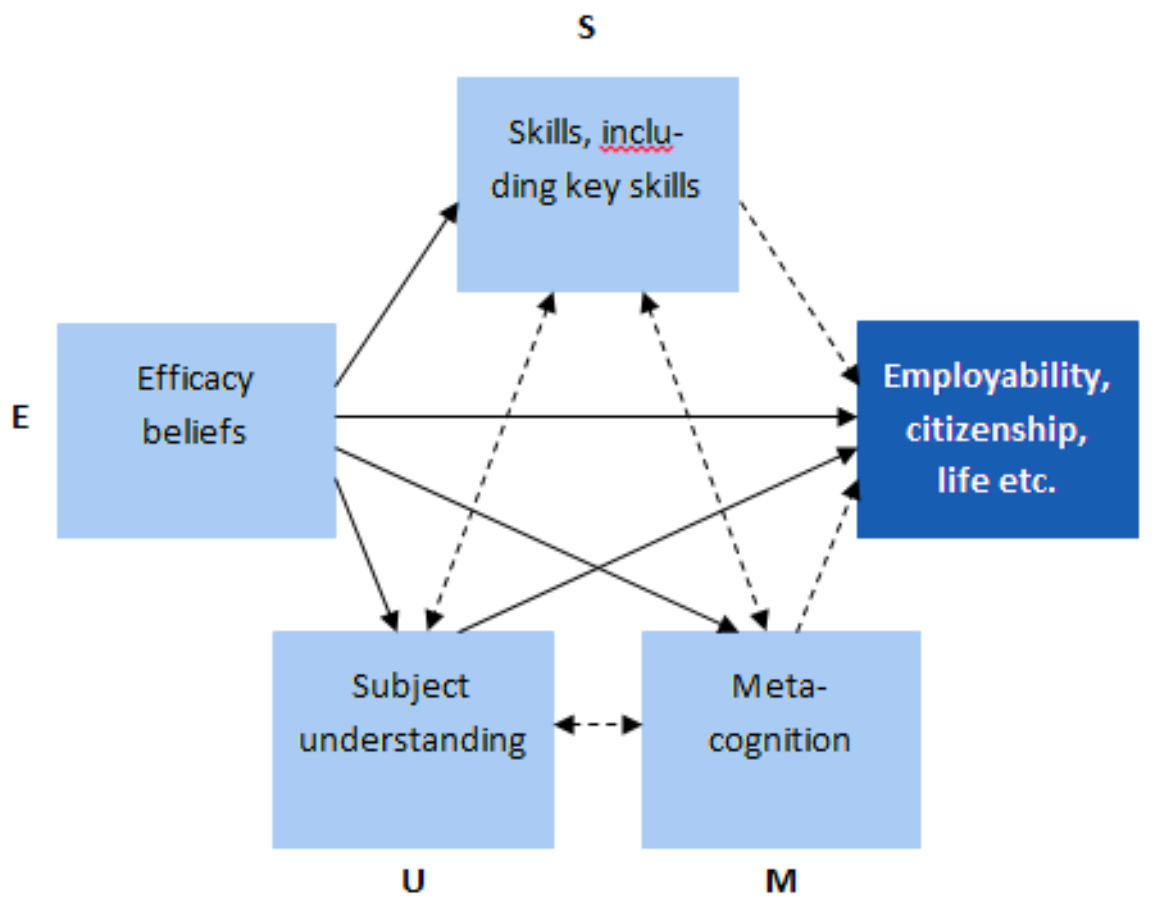

PICBE | 1070

Figure 1. USEM model

Source: Knight and Yorke, 2003, p. 265.

Understanding refers to the key outcomes of higher education in a professional field, skills comprise specific and general skills, and meta-cognition is a person's awareness about acting, learning, and developing one's skills. Efficacy beliefs are a person's self-theories, the belief 'to be able to make a difference' - $t$ thus influences all other three. This model describes a set of 39 dimensions of skills that "make an individual more likely to secure and be successful in their chosen occupation(s) to the benefit of themselves, the workforce, the community and the economy" (Knight and Yorke, 2003, p. 25).

Archer (2005) takes the employer's perspective and thus describes required key qualities: Intellectual ability, languages, business awareness (strategic vision, customer orientation, commercial awareness), planning and analysis (planning and organization, analysis and decision making), performance (achievement orientation, flexibility/change), empowerment (teamwork, leadership, personal development, communication skills) and international outlook (international mobility, cultural awareness) (Archer in (Shiel et al., 2005, p. 11). Harvey (2002) on the other hand explains, that employability does not just depend upon the labor market forces, but also on the "willingness" to learn and be employed (Harvey et al.; 2002).

Shiel et al. (2005) associate employability skills with globalization. To cope with a globalized and complex world an employee has to be self-reliant, connected, well-rounded (the individual's skills must reflect the global environment a person is working in), critical (reflecting on economic, social and political contexts, analyzing and making decisions) and a specialist in the respective field. They conclude that employers will increasingly search for employees "who understand the issues of sustainable development" (Shiel, 2005, p. 9).

Andrews and Higson distinguish between soft- and hard-skills. Business-related knowledge is described as hard skills, whereas interpersonal competencies, work 
experience and work-based learning are soft-skills (Andrews and Higson, 2008; Mason et al., 2009).

In Ismail and Mohammed's literature overview three categories are summarized: Core skills, which are defined as the technical competencies to efficiently use equipment and tools, generic skills, which are non-technical competencies (e. g. social skills), and personal attributes - the individual's attitudes and traits (Ismail and Mohammed, 2015).

PICBE | 1071

Stiwne and Alves in this context have shown that employers preferred personal attributes and skills to academic credentials when there is an increase in the supply of graduates (Stiwne and Alves, 2010). Thus they state that employers define employability as a person's behavioral competence and capacities rather than the traditional academic, theoretical knowledge.

Though the terms, the wording, the amount and the perspectives differ, all these specifications of employability skills have in common to distinguish between intangible aptitudes related to the specific individual and tangible skills which are a measurable outcome of education (in form of academic achievement and degrees) and further training (Knight and Yorke, 2004; Pietro and Cutillo, 2006; Andrews and Higson, 2008).

\section{Employability Skills in the outsourcing industry}

Human Capital is becoming more important as the international economy becomes more digitalized and services oriented. Regarding the hard and soft skills needed by the outsourcing industry the academic literature remains understudied so far - especially concerning the soft skills needed by the BPO industry. The majority of studies relate to investments in IT and language skills. Therefore, the authors' approach is to define the needs of the outsourcing industry in terms of hard and soft skills as well as personal attributes in the Romanian industry, deriving from the factors affecting location competiveness, business services provided and from the literature related to the future trends in work force.

\section{Hard Skills}

To define the competitive advantage of a country concerning an industry many factors must be regarded. Often a country index is created to compare advantages. One of the most popular indexes for the business process outsourcing industry is the A.T. Kearney Global Services Location Index. This index comprises three categories financial attractiveness (40\%), people skills and availability (30\%) as well as business environment (30\%) (percentages indicate the weight of the category).

Due to the emphasis of this article the main dimensions with respect to skill availability of the index are shown in table 1. 
Table 1. Assessment criteria for skill availability of the A.T. Kearney Global Services Location Index

\begin{tabular}{|l|l|l|}
\hline Category & Dimension & Metrics used \\
\hline $\begin{array}{l}\text { People skills and } \\
\text { availability }\end{array}$ & $\begin{array}{l}\text { Cumulative services } \\
\text { experience and skills }\end{array}$ & $\begin{array}{l}\text { Estimated size of IT and BPO sectors } \\
\text { Quality and skill rating for relevant positions } \\
\text { (quality of management school, college education } \\
\text { quality, relevant industry certifications, for IT, BPO, } \\
\text { and contact centers) }\end{array}$ \\
\cline { 2 - 3 } & Labor force availability & $\begin{array}{l}\text { Population ages 15 to 39 } \\
\text { Total tertiary enrollment Educational skills } \\
\text { Scores on standardized tests to assess student } \\
\text { performance }\end{array}$ \\
\cline { 2 - 4 } & Language skills & $\begin{array}{l}\text { Scores on standardized education and language } \\
\text { tests }\end{array}$ \\
\hline $\begin{array}{l}\text { Business } \\
\text { environment }\end{array}$ & Cultural Adaptability & $\begin{array}{l}\text { A.T. Kearney Globalization Index personal contact } \\
\text { rank }\end{array}$ \\
\hline
\end{tabular}

Source: 2016 A.T. Kearney Global Services Location IndexTM.

The index gives an initial idea on the main skills the BPO industry is looking for. Language and IT knowledge in addition to cultural adaptability play an important part in terms of hard skills. Change management as well as process management skills are derived from the nature of the business which demands processes to standardize work.

Another dimension regarding technical skills is derived from the services outsourced in the global and Romanian BPO industry which are, according to the latest Deloitte's 2016 Global Outsourcing Survey; IT (72\%), Legal (63\%), RE \& FM (60\%), Tax (53\%), HR (47\%), Finance (42\%) and Procurement (41\%) (Deloitte, 2016). According to the latest Association of Business Service Leaders and KPMG report the main outsourced services in Romania are in descending order of relevance: IT Services, Customer Operations, Finance \& Accounting, Human Resources, Procurement, Project Management, Business Transformation, Document Management, Marketing and Supply Chain Management (2016).

\section{Soft Skills}

Many studies relate to soft skills in general without further specification. There is only scarce literature concerning soft skills required by the BPO industry.

Despite the differentiation in the type of service provided all the BPO services have in common that the industry requires voice or non-voice based communication dealing with the partner or customer and therefore demanding very good command of communications skills - either written or verbal (Dubey, 2015). Customer orientation is required by the industry to know the customer and understand its needs. Attention to detail is necessary to efficiently compare information and detect errors. Empathy refers to consideration and friendliness of contact towards the customer. In addition, there is a great demand of learning abilities which are decribed as the willingness to understand a new product, system, process or service information (Barrios et al., 2013). Problem solving \& analysis as well as time management are often needed to rapidly solve issues along the outsourced service (Subramanian, 2005). 


\section{Skills for the future work force}

The BPO sector as well as other industries is going through a phase of disruption. The rapid rise of digitalization through the advancements in technology and robotics allow a high degree of automation and standardization. This puts the workforce in the BPO sector under pressure as many of the BPO companies have their comparative advantage around the efficient management of workforce and processes. Now a new scenario opens and there is a PICBE | 1073 need to deliver more value-added services that do not only rely on routine tasks which can be automated. This confronts the industry with the demand of new skills (Gott \& Sethi, 2016).

According to the latest research we will limit to only new skills demanded by the disruption of work to avoid duplication.

In the phase of rapidly rising computer power and big data it is crucial to be able to analyze large data sets and consequently derive conclusions to allow better customer service or product placement. Creativity and innovation will also become essential for the development of high value added products (World Economic Forum, 2016).

There is also a need for self-management skills such as the ability to multitask and organize different processes and work streams, flexibility to accept and manage continuous change and adapt to it. Due to the continuous change at a fast pace and the need to continuously upskill, employees will be phasing pressure and will need to be resilient to cope with a changing environment (Van der Zee, et. al.; 2009).

Through the shift from command and control organizations towards more collaborative management styles and the continuance of offshoring teaming skills will be as well of importance (Oxford Economics, 2012).

According to a report conducted by the University of Glasgow on the assessment of skills for the business services industry in the UK there is a gap in the workforce skills regarding proactivity in business acumen to derive critical business implications from the data managed. The report mentions that especially in contact centers staff is required to develop a service attitude by being positive and enthusiastic towards resolving the customers' queries (Sutherland, Mc Tier, Mc Gregor, 2015).

\section{Methodology, data analysis and results Methodology}

The analysis done was based on the qualitative content analysis of Mayring (2014). The following research question was deduced: "Which are the employability skills needed by the Romanian BPO industry?"

Based on the previous literature review a category system was defined for the purpose of the samples' analysis. Table 2 shows the defined categories divided into hard skills, soft skills and personal attributes. 
Table 2. Skills categories analyzed

\begin{tabular}{|l|l|l|}
\hline Hard Skills & Soft Skills & Personal Attributes \\
\hline Languages & Analysis and Problem Solving & Learning \\
\hline IT & Communication & Flexibility \\
\hline & & \\
Data Entry / Data Analysis & Team Work & Enthusiastic \& Positive \\
\hline Accounting / Finance & Customer Service Orientation & Resilience \\
\hline Project Management & Proactivity / Business Acumen & Results oriented \\
\hline Process Management & Attentiveness & Innovation \\
\hline Sales Knowledge & Autonomous work & Ethical skills \\
\hline Teaching & Time Control / Prioritization & Empathy \\
\hline Human Resources & Multitasking & \\
\hline Warranty knowledge & Organizational skills & \\
\hline Procurement Knowledge & Cultural Awareness & \\
\hline Change Management & Negotiation Skills & \\
\hline & Soft Skills & \\
\hline
\end{tabular}

PICBE | 1074

Source: Authors' own research results/contribution.

The data analyzed was coded by two independent researchers in order to reach a higher objectivity.

\section{Data analyzed}

The data base comprises 91 job descriptions of 10 international players of the outsourcing industry with a location in Romania. These job descriptions were advertised on independent job portals as well as on the career sites of the selected companies within the last quarter of 2016 and first month of 2017. They were limited to the following outsourcing areas: Customer Service, IT, HR, Procurement and Accounting as these are the major outsourced sectors in Romania. Table 3 shows the sample structure

Table 3. Sample structure of job descriptions analyzed

\begin{tabular}{|l|c|}
\hline \multicolumn{1}{|c|}{ Row Labels } & Count of Department \\
\hline Customer Service & 33 \\
\hline IT & 29 \\
\hline Finance \& Accounting & 9 \\
\hline Sales & 8 \\
\hline HR & 5 \\
\hline Business Intelligence & 3 \\
\hline Data Entry & 2 \\
\hline Procurement & 2 \\
\hline Grand Total & $\mathbf{9 1}$ \\
\hline
\end{tabular}

Source: Authors' own research results/contribution

The location of the jobs has been limited to Bucharest since approx. $55 \%$ of the BPO business in Romania is located in Bucharest (Marks, M., 2015). The job descriptions were addressed as graduate or entry positions, therefore not requiring more than 0-1 years of experience. Seasonal variations have not been excluded. Nonetheless this analysis should give a first indication of the requirements of the market. In addition, positions which did not state years of experience were double reviewed based on the experience and activities required by the job position, assuming that more complex strategic activities as well as departmental leadership are demanded by more senior managers. Job advertisements fulfilling latter criteria were disregarded from the analysis. The analysis was limited to the 
specific qualifications required by the job description. The key responsibilities specified by the job have been left out as this left room for subjectivity while could be analyzed in further research.

\section{Results analysis Hard skills}

The most required hard skills by the Romanian outsourcing industry are languages and IT knowledge (see figure 2).

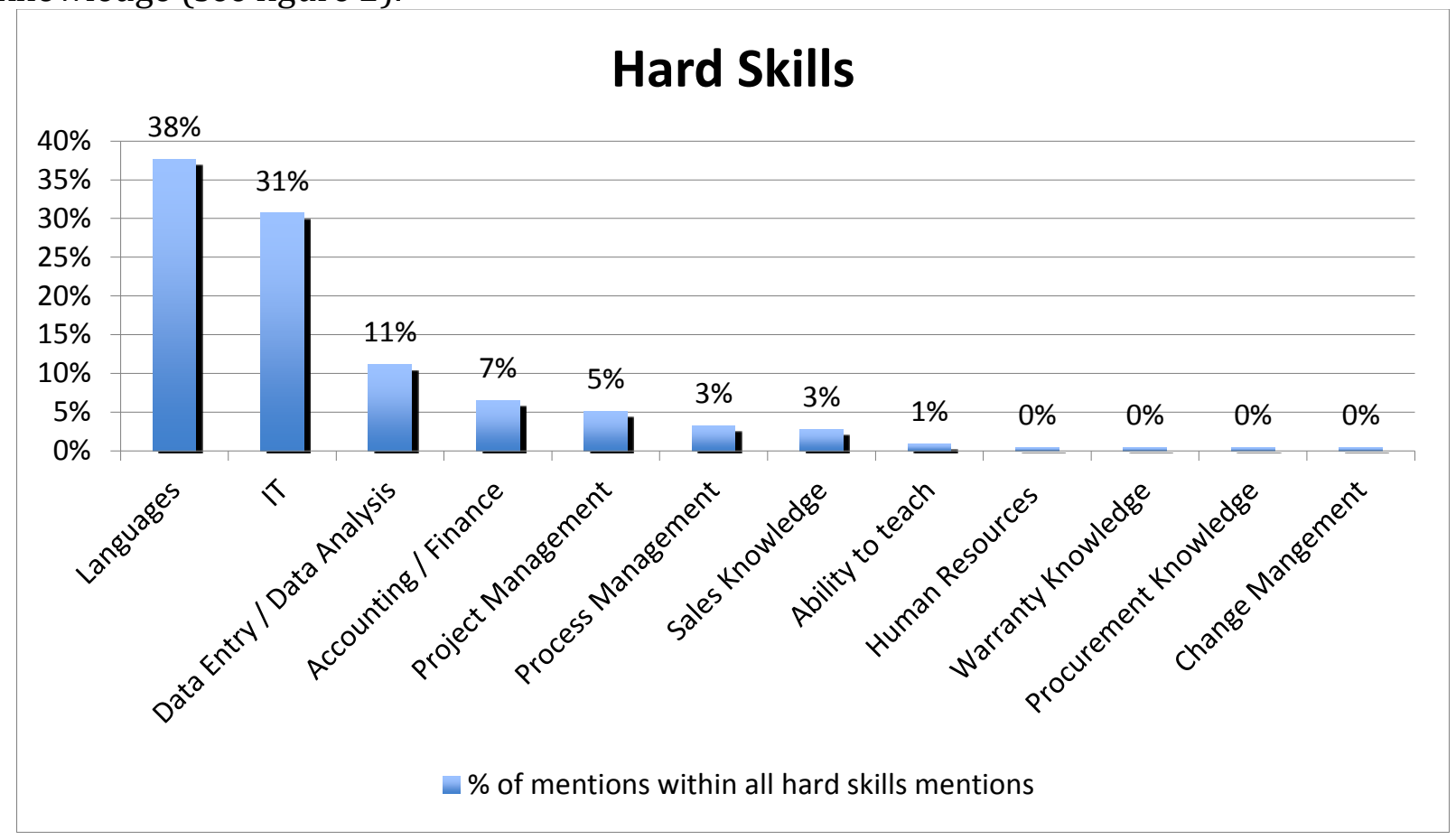

Figure 2. Hard Skills

Source: Authors' own research results/contribution.

This emphasizes the importance the industry continues to give to IT knowledge by requiring a medium to high knowledge of IT. The knowledge requirement ranges from Medium Microsoft Office usage to very senior programming skills in different types of programming languages. In addition very good social media and web applications command is appreciated. As for languages, the main language needed is English followed by further European languages. Very often the job descriptions require the command of two foreign languages with English as first required language and another European language as second.

Specific knowledge of the commonly outsourced processes is very little mentioned within the qualification requirements of the jobs' profiles for graduates, with exception of data base entry and finance/ accounting (see figure 2). In respect to technical skills referring to project management and process management the demand was higher compared to the outsourced service knowledge. This goes in line with literature review and demand of these specific skills. Only in one job description the knowledge of change management was mentioned. This is an unexpected result. Due to the fast changes in industry and technology a higher amount of mentions in this skill was expected. This will 
need further analysis for explanation as well as why the specific knowledge of the outsourced service is so scarcely mentioned.

\section{Soft Skills}

The picture within the soft skills shows a much more differentiated view as a variety of soft skills are demanded.

PICBE | 1076

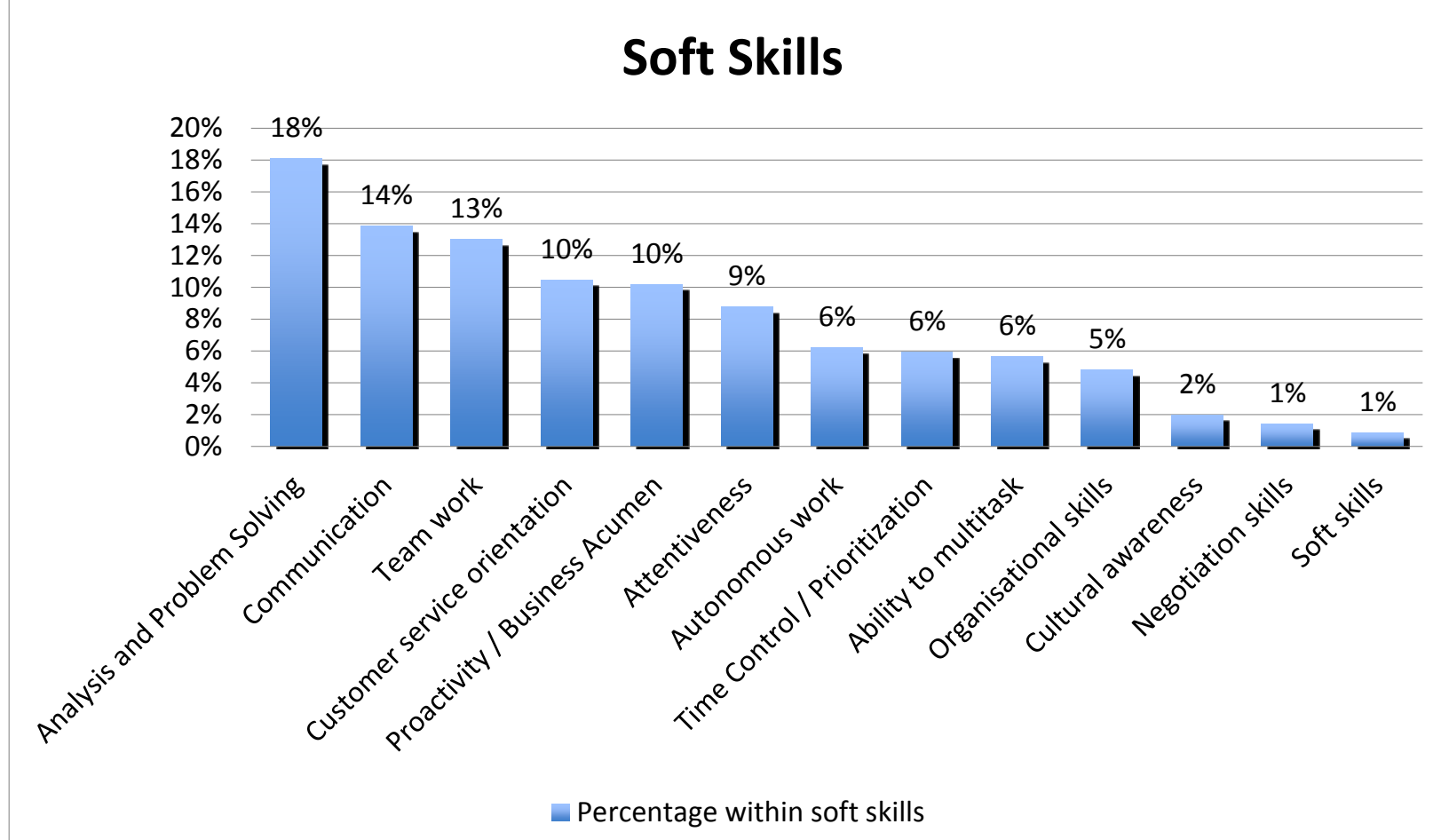

Figure 3. Soft Skills

Source: Authors' own research results/contribution.

The percentage distribution of number of mentions between hard skills (32\%), soft skills (53\%) and personal attributes (13\%) within the data sample shows that soft skills are in higher demand. This allows the authors to create the hypothesis that BPO companies are giving a higher importance to soft skills than hard skills. However this would need validation through further research.

According to the results within the soft skills the authors distinguish a grouping of skills according to the number of mentions. The first group of soft skills with the highest number of mentions are customer-centric skills. These are skills needed to create a good customer experience and resolution of queries. The skills within this group are analysis and problem solving, very good command of communication skills, team work, customer service orientation and proactivity and business acumen (see figure 3).

The second group of skills is employee-centric and allows an employee to cope well with the variety of processes and tasks to be delivered within a specific time frame with a low number of errors. These are: attention to detail, autonomous work, time control and ability to prioritize, ability to multitask as well as organizational skills.

Negotiation skills and cultural awareness were the soft skills with the least number of mentions. The fact that negotiation skills are in little demand can probably be explained through the fact that the business follows standardized processes that leave very little room 
for negotiation. The modest demand of cultural awareness can be explained through the cultural proximity to the countries served by the Romanian BPO sector which are mainly in Western Europe and Central East Europe including Romania (ABSL \& KPMG, 2016).

Finally, 'soft skills' in general were mentioned three times however due to the vagueness of the skill and the high amount of specifications of soft skills the authors refrained from further analysis of these mentions.

PICBE | 1077

\section{Personal Attributes}

Within the personal attributes required by the industry the results of the analysis show that three of the eight selected attributes within this group cover $63 \%$ of the mentions, namely a learning attitude, flexibility and an enthusiastic positive mindset (see figure 4).

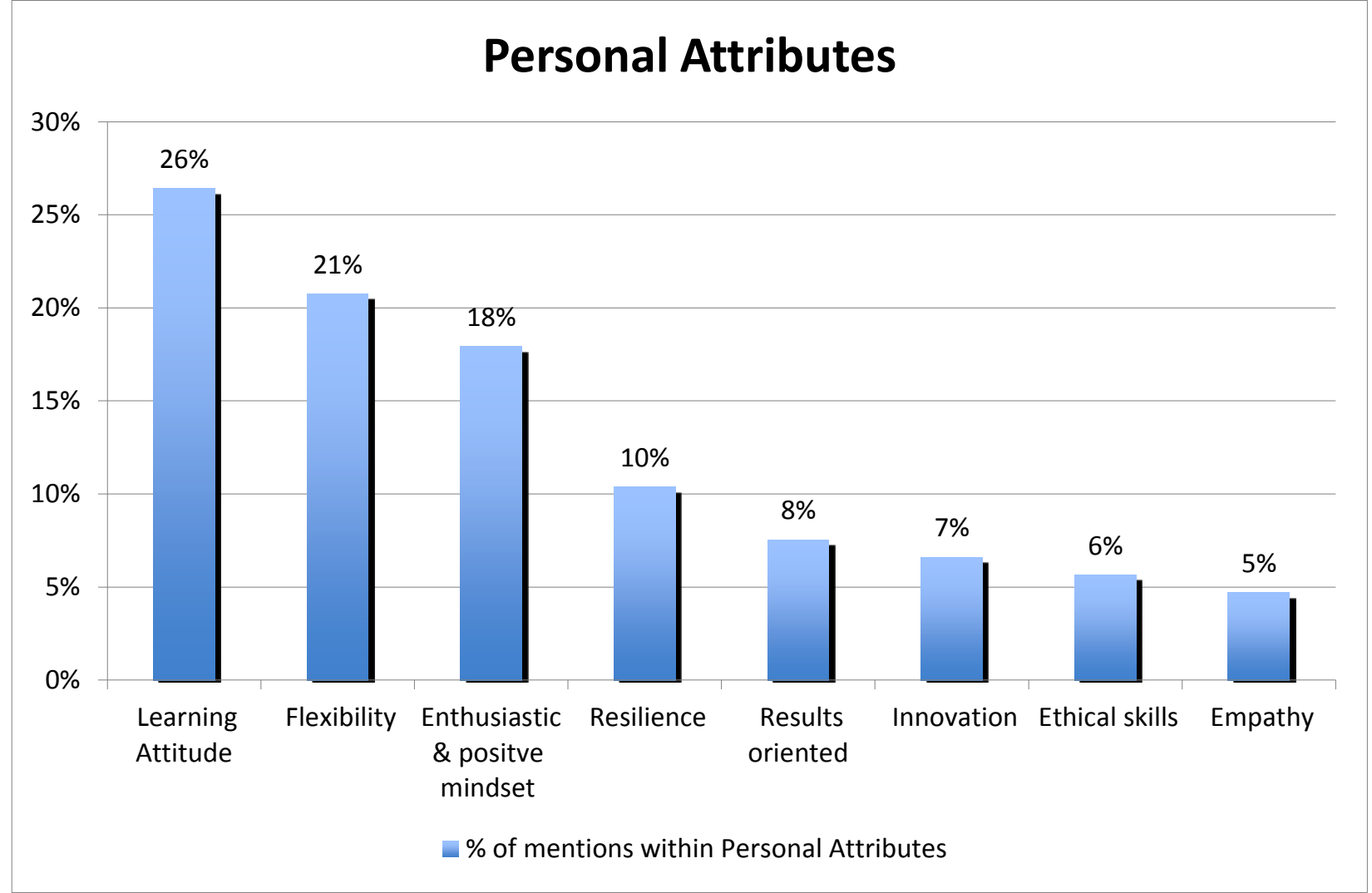

Figure 4. Personal Attributes mentions

Source: Authors' own research results/contribution.

The fact that a learning and flexible attitude are in demand reflects the need to adapt to a rapidly changing environment driven by digitalization. An enthusiastic and positive attitude towards an ever changing environment and the potential distress of customers in demand of a service seem to be as well of importance.

A resilient as well as a results oriented attitude appear to have more importance than creativity and empathy. Innovation is not much in demand amongst graduates as they need to understand the business and its processes first prior to product and business development. Finally, ethical skills have been mentioned 6 times, however only by 3 companies. Therefore, the mention of this category could be explained by the code of conduct of the specific company which requires ethical values.

Table 4 shows a summary of the above discussion. 
Table 4. Summary of key results

\begin{tabular}{|c|c|c|c|c|}
\hline $\begin{array}{l}\text { Employability } \\
\text { Skills }\end{array}$ & \multicolumn{4}{|c|}{ Romanian BPO Industry } \\
\hline Skill Category & Hard & \multicolumn{2}{|c|}{ Soft } & Personal Attribute \\
\hline Relation & & $\begin{array}{l}\text { Customer } \\
\text { Centric }\end{array}$ & Employee Centric & \\
\hline Specific Skill & $\begin{array}{ll}+ & \text { IT } \\
+ & \text { Languages } \\
\circ & \text { Data analysis } \\
\text { ○ } & \text { Project \& } \\
& \text { process } \\
& \text { management } \\
- & \text { Specific } \\
& \text { outsourced } \\
& \text { function } \\
& \text { knowledge }\end{array}$ & $\begin{array}{ll}+ & \text { Analysis \& } \\
& \text { problem solving } \\
+ & \text { Communication } \\
+ & \text { Team work } \\
+ & \text { Customer service } \\
& \text { orientation } \\
-\quad & \text { Cultural } \\
& \text { awareness }\end{array}$ & 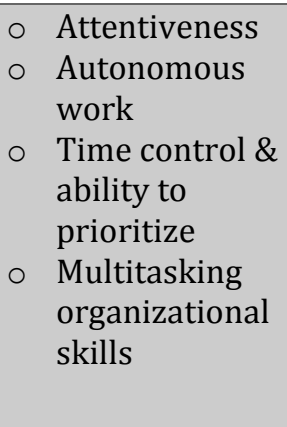 & $\begin{aligned}+ & \text { Learning } \\
& \text { Attitude } \\
+ & \text { Flexibility } \\
+ & \text { Positive } \\
& \text { Enthusiastic } \\
0 & \text { Resilient } \\
0 & \text { Results } \\
& \text { oriented } \\
- & \text { Creativity } \\
- & \text { Empathy }\end{aligned}$ \\
\hline Higher imp & ance & le importance & ss importance & \\
\hline
\end{tabular}

PICBE | 1078

\section{Conclusions}

The key findings of this paper show that the Romanian Business Process Outsourcing Industry is as well following the trend of the Industrial Revolution 4.0 in terms of employability skills. This said, there seems to be a shift in the skills demanded by the industry from technical skills towards more intangible skills.

This paper has given an initial direction for further research such as to deepen how much technical skills in specific services such as HR, Finance and Accounting, Procurement are still needed based on the era of digitalization in the BPO sector.

This is a first important step to determine the employability skills required by the business process sector in Romania. In a second step it gives guidance regarding the skills in demand by the industrial revolution 4.0. Therefore, it intends to provide direction to the educational sector by giving insight on the requirements of the business sector in terms of skills needed.

Further research should focus on the educational system which supports this sector in order to analyze how big the gap is between the skills in demand and the educational system.

Although job descriptions are indicators to provide an objective measure of business requirements, these do not describe the level of competence needed. It is important, that the precise level of skill attributes is understood by candidates and universities in order to demonstrate ability and teach respectively. 


\section{References}

AT Kearney. (2016). Global Services Location Index Report. Retrieved from Retrieved from https://www.atkearney.com/documents/10192/7094247/On+the+Eve+of+Disruption.pdf /49fa89fa-7677-4ab8-8854-5003af40fc8e.

ABSL, KPMG. (2016), Outsourcing Industry Report Retrieved from http://www.absl.ro/sites/default/files/absl_romania_industry_report_2016.pdf.

PICBE | 1079

Andrews, J. and Higson, H. (2008). Graduate Employability, 'Soft Skills' Versus 'Hard' Business Knowledge, A European Study. Higher Education in Europe 33(4), 411-422. doi: $10.1080 / 03797720802522627$.

Barrios, E., Gauran, I. I., Lansangan, J. R., Nalica, A., Santos, K. C., \& Sarte, G. M. (2013). Competency of Graduating students and Entry Level workers in IT-BPO industry, $12^{\text {th }}$ national Convention on Statistics, Mandalung.

Bridgstock, R. (2009). The graduate attributes we've overlooked: enhancing graduate employability through career management skills, Higher Education Research \& Development, 28(1), 31-44.

Deloitte. (2016). Deloittes 2016 Global Outsourcing Survey, Retrieved from https://www2.deloitte.com/content/dam/Deloitte/nl/Documents/operations/delo itte-nl-s\&o-global-outsourcing-survey.pdf.

Dubey, M. (2015). Employability Skill Development - An Industry Academia Analysis for BPO Industry, JSSGIW Journal of Management, II( 1), Oct-Mar 2015, 106.

Gott J. \& Sethi A. (2016), On the eve of Dirsruption, A new business model threatens established concepts of offshoring and expands the market. Retrieved from https://www.atkearney.com/documents/10192/7094247/On+the+Eve+of+Disruption.pdf /49fa89fa-7677-4ab8-8854-5003af40fc8e.

Marks M. (2015), Rumaenien mit Starker Outsourcing Branche, Germany Trade and Invest Retrieved from http://www.gtai.de/GTAI/Navigation/DE/Trade/Maerkte/suche, $\mathrm{t}=$ rumaenien-mit-starker-outsourcingbranche,did=1360268.html.

Harvey, L., Locke, W. and Morey, A. (2002). Enhancing Employability, Recognising Diversity: Making Links between Higher Education and the World of Work. London: Universities UK.

Hillage, J. and Pollard, E. (1998). Employability: Developing a Framework for Policy Analysis, DfEE Research Report RR85, November 1998. Department for Education and Employment: London.

Ismail, S. and Mohammed, D.S. (2015). Employability Skills in TVET Curriculum in Nigeria Federal Universities of Technology. Procedia - Social and Behavioral Sciences 204, 73-80. doi: 10.1016/j.sbspro.2015.08.111.

Knight, P.T. and Yorke, M. (2003). Employability and good Learning in Higher Education. Teaching in Higher Education 8(1), 3-16. doi: 10.1080/1356251032000052294.

Mason, G., Williams, G. and Cranmer, S. (2009). Employability skills initiatives in higher education: what effects do they have on graduate labour market outcomes? Education Economics 17(1). 1-30. doi: 10.1080/09645290802028315.

Mayring, P. (2014). Qualitative content analysis: theoretical foundation, basic procedures and software solution. Klagenfurt. Retrieved from http://nbnresolving.de/urn:nbn:de:0168-ssoar-395173.

Outsourcing Today (2016), "Addressing the pressing needs of digitalization and people empowerment", 1(3), 26-34. 
Oxford Dictionary Online, Retrieved from https://en.oxforddictionaries. com/definition/skill, 19.01.2017).

Oxford Economics (2012). Global Talent 2021 How the new geography of talent will transform human resource strategies. Retrieved from https://www.oxfordeconomics.com/Media/Default/Thought\%20Leadership/global -talent-2021.pdf.

PICBE | 1080

Pietro, G.D. and Cutillo, A. (2006). University quality and labour market outcomes in Italy. Labour, 20(1), 37-62.

Shiel, C., Williams, A. and Mann, S. (2005). Global Perspectives and Sustainable Development in the Curriculum: Enhanced Employability, More Thoughtful Society? In Newland, B., Norman, K. and Johnson, M. (eds.). Enhancing graduate employability, the Roles of learning, Teaching, Research and Knowledge Transfer. Proceedings of the Bournemouth University Learning and Teaching Conference, 63-77, Poole: Bournemouth University.

Stiwne, E.E. and Alves, M.G. (2010). Higher Education and Employability of Graduates, Will Bologna Make a Difference? European Educational Research Journal 9(1), 32-44. doi: 10.2304/eerj.2010.9.1.32.

Subramanian, R. (2005). Soft Skills Training and Culutral Senzitation of Indian BPO workers: A Qualitative Study, Communications of the IMMA, 5 (2), Artcl. 2

Sutherland V. ,Mc Tier A., Mc Gregor A. (2015). Skills Assessment for Business Services Final Report, Training and Employment Research Center, University of Glasgow.

Van der ZEE, F., Dr., \& E. (2009). Investing in the Future of Jobs and Skills Scenarios, implications and options in anticipation of future skills and knowledge needs Sector Report Computer, Electronic and Optical Products Retrieved from http://people.few.eur.nl/dijkgraaf/Epubs/2009\%20lot\%204\%20Final\%20report\% 20Lot\%204\%20-\%20Chemicals\%20100709.pdf.

World Economic Forum. (2016). Global Challenge Insight Report -The Future of Jobs Employment, Skills and Workforce Strategy for the Fourth Industrial Revolution. Retrieved from http://www3.weforum.org/docs/WEF_Future_of_Jobs.pdf. 